\title{
Stomatal and non stomatal limitation of photosynthesis by leaf water deficits in three oak species: a comparison of gas exchange and chlorophyll a fluorescence data
}

\author{
D Epron, E Dreyer *
}

\begin{abstract}
INRA-Nancy, Laboratoire de Bioclimatologie et d'Écophysiologie Forestières, Station de Sylviculture et Production, Champenoux, F-54280 Seichamps, France
\end{abstract}

(Received 5 April 1990; accepted 6 June 1990)

\begin{abstract}
Summary $-\mathrm{Net} \mathrm{CO}_{2}$ assimilation (A), stomatal conductance for $\mathrm{CO}_{2}(g)$, intercellular mole fraction of $\mathrm{CO}_{2}\left(C_{i}\right)$, kinetics of chlorophyll a fluorescence, and their half decay time $\left(t_{1 / 2}\right)$, their ratio of fluorescence decrease $\left(R_{f o}\right)$, and their adaptive index $\left(A_{0}\right)$ have been monitored on potted trees from 3 oak species (Quercus petraea, $Q$ pubescens and $Q$ liex) grown in a climate chamber and submitted to drought. Use of $A$ vs $C_{i}$ representations for photosynthesis data revealed an apparent impairment of mesophyll photosynthesis, together with reduced $\mathrm{CO}_{2}$ supply to mesophyll due to stomatal closure. But in all species chlorophyll a fluorescence kinetics displayed very similar shapes, constant $t_{1 / 2}$ and stable $R_{f d}$ and $A_{p}$ values until predawn leaf water potential dropped below $-4.0 \mathrm{MPa}$. These observations led to the conclusion that photochemical energy conversion and photosynthetic carbon reduction cycle could be very resistant to leaf water deficits, and that observed decreases in mesophyll photosynthesis had to be attributed to a possible artefact in $C_{\mathrm{i}}$ calculation. On the other hand, the susceptibility of leaves to photoinhibition increased as a consequence of water shortage, especially in $Q$ petraea and $Q$ pubescens. Differences in drought adaptation between the studied species could probably be related to susceptibility to photoinhibition rather than to a direct sensitivity of photosynthesis to leaf water deficits, at least in the range of stress intensities of ecophysiological significance.
\end{abstract}

photosynthesis / water stress / chlorophyll a fluorescence / oak / stomatal conductance / drought / photoinhibition

Résumé - Limitation d'origine stomatique et non stomatique de la photosynthèse de trois espèces de chêne soumises à la sécheresse : comparaison de mesures d'échanges gazeux et de fluorescence de la chlorophylle. Les échanges gazeux foliaires et la fluorescence de la

* Correspondence and reprints.

Abbreviations: $A=$ net $\mathrm{CO}_{2}$ assimilation rate; $A_{\max }=\mathrm{A}$ at saturating $\mathrm{Ci} ; A_{p}=$ adaptative index; $C_{i}=$ intercellular $\mathrm{CO}_{2}$ molar fraction; $d A d d C i=$ carboxylation efficiency; $F_{p}$ and $F_{t}=$ maximal and terminal fluorescence levels; $g=$ stomatal conductance for $\mathrm{CO}_{2} ; L W C=$ leaf water content; $P_{i}=$ inorganic phosphate; $P P F D=$ photosynthetic photon flux density; $P S / I$ and $P S I=$ photosystem II and $\mathrm{I} ; R_{f d}=$ ratio of fluorescence decrease; $t_{1 / 2}=$ fluorescence half-decay time; $\alpha=$ apparent quantum yield of photosynthesis; $\psi_{\mathrm{wp}}=$ predawn leaf water potential; $\Delta w$ : leaf to air water vapour molar fraction difference 
chlorophylle ont été étudiés lors d'une sécheresse édaphique imposée en conditions contrôlées, sur de jeunes plants de Quercus patraea, $Q$ pubescens et $Q$ ilex. L'analyse des relations entre assimilation nette de $\mathrm{CO}_{2}$ (A) et fraction molaire intercellulaire calculee de $\mathrm{CO}_{2}\left(\mathrm{C}_{\mathrm{j}}\right)$ semble indiquer que l'inhibition de $A$ a résulté à la fois d'une fermeture des stomates, mais aussi d'une altération des processus mésophylliens de la photosynthèse. Par contre, la forme des cinétiques de fluorescence de la chlorophylle réalisées in vivo ainsi que les valeurs de $\mathrm{t}_{1 / 2}$ (temps de demi décroissance), $\mathrm{R}_{\mathrm{fd}}$ (rapport de décroissance de fluorescence) ou de A (index d'adaptation) n'ont pas été affectées tant que le déficit hydrique foliaire n'avait pas atteint un niveau élevé (potentiel hydrique de base inférieur a $-4,0$ MPa). Ceci semble indiquer une grande résistance de l'appareil photosynthétique au déficit hydrique foliaire. Par contre, l'étude de la réaction de la photosynthèse aux forts éclairements a révélé une sensibilité accrue à la photo-inhibition chez $Q$ petraea et $Q$ pubescens lors d'une sécheresse édaphique, contrairement à ce qui a été observé pour $\mathrm{Q}$ ilex. Les différences d'adaptation à la sécheresse existant en conditions naturelles entre ces 3 espèces pourraient être due à une sensibilité accrue à la photo-inhibition plutôt qu'à une sensibilité directe de l'appareil photosynthétique au déssèchement foliaire, du moins dans la gamme des déssèchements les plus fréquemment rencontrés en conditions naturelles.

photosynthèse / stress hydrique / fluorescence / chêne / conductance stomatique / sécheresse / photo-Inhibition

\section{INTRODUCTION}

European oak species grow in habitats differing widely in the frequence of drought occurrence. Quercus petraea (subgenus Lepidobalanus section robur); as a mesophytic mid European species is rather sensitive to water shortage, while $Q$ pubescens (subgenus Lepidobalanus section robur) grows in much drier soils. $Q$ ilex (subgenus Lepidobalanus section ilex), a Mediterranean sclerophyllous xerophyte, is sometimes submitted to long periods of water deficits accompanied by high levels of solar irradiance.

Differences in drought tolerance between species may be partly due to differential sensitivities of photosynthetic processes in leaves to tissue dehydration. But it is still unclear whether water shortage and resulting leaf water deficits have direct effect on the mesophyll processes of photosynthesis (photochemical energy conversion and/or carbon metabolism), or only indirect effects via stomatal closure and subsequent limitations of $\mathrm{CO}_{2}$ diffusion to chloroplasts.
Some studies with chloroplastic suspensions or enzyme extracts have reported the occurrence of both reductions in photochemical processes (Boyer, 1976) and in ribulose-biphosphate carboxylase-oxygenase activity (Vu et al, 1987).

Leaf gas exchange measurements and analysis using diffusion models (Jones, 1973, 1985; Farquhar and Sharkey, 1982) have frequently led to the result that leaf water deficits impair both mesophyll ability to assimilate $\mathrm{CO}_{2}$, and $\mathrm{CO}_{2}$ diffusion to chloroplasts (Jones and Fanjul, 1983; Teskey et al, 1986; Cornic et al, 1987; Grieu et al, 1988). In these studies, net assimilation was analysed as a function of calculated intercellular $\mathrm{CO}_{2}$ mole fraction $\left(C_{i}\right)$; in almost all stress situations, reductions seemed to occur at fairly constant $C_{i}$ values, therefore displaying both diffusional and biochemical limitations of photosynthesis (Jones, 1973, 1985; Cornic et al, 1983). However, recent results suggest that this model may be misleading, due to artefacts in $C_{j}$ calculation (Terashima et al, 1988).

In order to test potential limitations induced by water stress on carbon assimila- 
tion of leaves in vivo on our 3 oak species, we compared the results obtained with gas exchange measurements and with chlorophyll a fluorescence kinetics.

Chlorophyll a fluorescence kinetics, based on the Kautsky effect, allow the assessment to be made of possible impairments in:

- energy conversion at PSII level (variable fluorescence); and

- in the transfer of electrons from the first acceptors to the photosynthetic carbon reduction cycle (fluorescence decrease) (Krause and Weis, 1984; Briantais et al, 1986). In this study, we analysed the shapes of fluorescence decrease which is related to the onset of both photochemical and non photochemical quenching, and calculated the half decay time $t_{1 / 2}$, the ratio of fluorescence decrease $\left(R_{f d}\right.$; Lichthenthaler et al, 1986) and an adaptative index reflecting the degree of integrity of photosynthetic membranes ( $A_{p}$; Strasser et al, 1987). In addition, water stress often promotes susceptibility to photoinhibition (Krause, 1984). Susceptibility to photoinhibitory damages has therefore been compared in our species and related to the level of drought tolerance.

The aims of these experiments were to give an insight into the mechanisms of stress reactions, and to compare them in the 3 tree species known for their differences in drought tolerance.

\section{MATERIAL AND METHODS}

\section{Plant material and growth conditions}

The oak species studied were Quercus petraea Liebl (seed origin: Forêt Domaniale d'Amance, near Nancy, France), $Q$ ilex $L$ (seed origin: Mont
Ventoux, near Avignon, France) and $Q$ pubescens Willd (seed origin: Mont Ventoux).

Three-year-old ( $Q$ pubescens and $Q$ ilex) or 4-year-old ( $Q$ petraea) saplings were grown in 7-I plastic pots on a 1:1 ( $/ \mathrm{V} / \mathrm{V}$ mixture of brown peat and sandy soil, in a naturally illuminated greenhouse; they were fertilised 4 times a year during the growing season with a complete nutrient solution ( $N, P, K ; 7,6,9$; Solugene), and were watered twice a week with deionized water.

\section{Experimental time course}

One week before each experiment, the plants were transferred to a growth cabinet with following day/night conditions: $16 / 8 \mathrm{~h}$; air temperature, $22 / 16{ }^{\circ} \mathrm{C}$; relative humidity, $70 / 95 \%$. Photosynthetic photon flux density (PPFD) at the top of the plants was maintained at $300 \mu \mathrm{mol} \mathrm{m} \mathrm{m}^{-2} \mathrm{~s}^{-1}$ provided by neon lamps. Ambient $\mathrm{CO}_{2}$ molar fraction averaged $475 \pm 25 \mu \mathrm{mol} \mathrm{mol}^{-1}$.

Measurements were performed during May 1989 for $Q$ pubescens, June 1989 for $Q$ petraea and July 1989 for $Q$ ilex. For each species, 2 control saplings were watered daily and 4 or 5 plants were exposed to water shortage by withholding irrigation for about $20 \mathrm{~d}$. Small amounts of water were added to the pots when needed, to avoid death of plants. Predawn leaf water potential, net $\mathrm{CO}_{2}$ assimilation rate and chlorophyll fluorescence kinetics were studied $2 \mathrm{~d}$ a week for the water-stressed plants and only $1 d$ a week for the control. At the end of the stress period, a twig of 2 control and of 2 or 3 droughtstressed plants was exposed for $4 \mathrm{~h}$ to a PPFD of $2000 \mu \mathrm{mol} \mathrm{m} \mathrm{m}^{-2} \mathrm{~s}^{-1}$ provided by a sodium lamp (SON-T-400W, Philips) in order to assay susceptibility to photoinhibition. An electric fan was used to prevent thermal injury to the leaves. Apparent quantum yield of photosynthesis $(\alpha)$ and chlorophyll fluorescence were used to quantify possible photoinhibitory effects. To investigate the effect of rapid dehydration on chlorophyll fluorescence kinetics, 20 leaf discs were punched from a twig of a well-watered plant of $Q$ petraea. Five leaf discs were kept on a wet filter paper and 15 were submitted to dehydration in air for several $h$. This stress treatment was imposed in darkness at room temperature $(\approx$ $20^{\circ} \mathrm{C}$ ). 


\section{Water relations}

Predawn leaf water potential ( $\left.\psi_{\text {wp }}\right)$ was measured using a pressure chamber. Leaf water content ( $L W C$ ) was estimated after over-drying a leaf disk during $48 \mathrm{~h}$ at $60^{\circ} \mathrm{C}$. Each value of $\angle W C$ is the mean of 3 replicates.

\section{Gas exchange measurements}

Whole leaf gas exchange was measured in an open system designed in the laboratory. Net $\mathrm{CO}_{2}$ assimilation $(A)$ and transpiration $(E)$ rates were monitored with a differential infra-red gas analyser for both $\mathrm{CO}_{2}$ and water vapour (Binos, Leybold Heraeus). Two or 3 leaves ( $Q$ pubescens and $Q$ petraea) or $\approx 10$ leaves ( $Q$ ilex) were enclosed in a $2-1$ assimilation chamber, in which air temperature $\left(T_{e}\right)$, leaf-to-air water vapour molar fraction difference $(\Delta W)$ and ambient $\mathrm{CO}_{2}$ molar fraction $\left(C_{2}\right)$ were controlled. A gas stream of 2 I $\mathrm{min}^{-1}$ was provided continuously and monitored by a mass flow controller. $A$ tan homogenized the air inside the chamber. $\mathrm{CO}_{2}$ molar fraction of the air in the chamber $\left(C_{a}\right)$ was controlled by injecting pure $\mathrm{CO}_{2}$ into the main flux of $\mathrm{CO}_{2}$ free air. Air with a low oxygen concentration $\left(1 \% \mathrm{O}_{2}\right)$ was obtained when needed, from a mixture of $5 \% \mathrm{CO}_{2}$ free air $+95 \% \mathrm{~N}_{2}$. IIlumination provided from the growth cabinet was increased to $400 \mu \mathrm{mol} \mathrm{m} \mathrm{m}^{-2} \mathrm{~s}^{-1}$ with a sodium lamp (SON-T 400W, Philips), and monitored with a quantum sensor (Li 190SB, LiCor). Regulations and data acquisition were monitored by an application stored in a computer (AT3, IBM) via a data logger (SAM 80 AOIP). The means of 5 successive measurements were computed and stored every $10 \mathrm{~s}$. Stomatal conductance for $\mathrm{CO}_{2}(g)$ and intercellular $\mathrm{CO}_{2}$ molar fraction (C.) were calculated according to von Caemmerer and Farquhar (1981).

The following conditions prevailed in the assimilation chamber: $T_{a}, 22{ }^{\circ} \mathrm{C}$ and $\Delta \mathrm{w}, 8 \mathrm{mmol}$ $\mathrm{mol}^{-1}$. During the establishment of $\left(A, C_{a}\right)$ response curves, $P P F D$ was maintained at 400 $\mu \mathrm{mol} \mathrm{m}{ }^{-2} \mathrm{~s}^{-1}$ and $C_{\mathrm{a}}$ was changed every $15 \mathrm{~min}$ from 950 to $800,650,500,350,200$ and 50 $\mu \mathrm{mol} \mathrm{mol}^{-1}$. $\left(A, C_{2}\right)$ response curves were run $45 \mathrm{~min}$ after illumination, and values of $A$ and $g$ were recorded at the end of the period at 350 $\mu \mathrm{mol} \mathrm{mol}-1$. During the establishment of $(A$,
$P P F D$ ) response curves, $C_{a}$ was maintained at $950 \mu \mathrm{mol} \mathrm{mol}^{-1}$ in a $1 \% \mathrm{O}_{2}$ air and PPFD was changed every $30 \mathrm{~min}$ from 0 to 100,200, 300 $\mu \mathrm{mol} \mathrm{m} \mathrm{m}^{-2} \mathrm{~s}^{-1}$. (A, PPFD) response curves were run before and $30 \mathrm{~min}$ after the high-illumination treatment.

As defined by Jones $(1973,1985),(A, C$.j) response curves outline the mesophyll photosynthetic capacity (demand functions). The supply functions, defined as the lines with an $x$-axis intercept equal to $C_{\mathrm{a}}[1-E /(g+E / 2)]$ and a negative slope equal to $-(g+E / 2)$ (Guehl and Aussenac, 1987), give an estimate of diffusive limitations to $\mathrm{CO}_{2}$ assimilation. Stomatal and mesophyll components of $A$ limitation can be evaluated by considering the displacement of those 2 functions on the same $(A, C)$ graph. The initial slope of the $\left(A, C_{j}\right)$ response curve $\left(\mathrm{d} A / \mathrm{d} C_{i}\right.$ ) was calculated as an estimate of carboxylation efficiency. Apparent quantum yield of photosynthesis $(\alpha)$ was computed as the initial slope of the (A, PPFD) response, obtained in a $1 \% \mathrm{O}_{2}$ air mixture to limit photorespiration.

\section{Chlorophyll a fluoresence measurements}

The slow induction transients of in vivo chlorophyll fluorescence were measured at room temperature with the apparatus described by Lichtenthaler and Rinderle (1988). Fluorescence of 30-min dark -adapted leaf disks was excited by an $\mathrm{He}-\mathrm{Ne}$ laser (215, Spectra Physics; $5 \mathrm{~mW}, \lambda$ $=632.8 \mathrm{~nm}$ ) using $1 \mathrm{arm}$ of a 3-arm glass-fibre optic, and guided by the other arms to detecting photodiodes (SD 444-41-11-261, Silicon Detector Corp). The exciting red light at leaf surface amounted to $\approx 400 \mu \mathrm{mol} \mathrm{m}^{-2} \mathrm{~s}^{-1}\left(80 \mathrm{~W} \mathrm{~m}^{-2}\right)$. A red cut-off filter (Schott RG 665) was used to exclude excitation light and interference filters (Schott DAL, $\lambda \max 691 \mathrm{~nm}$ or $732.9 \mathrm{~nm}$ ) were applied to sense the fluorescence induction kinetics simultaneously in the 690 or $735 \mathrm{~nm}$ spectral regions. Both fluorescence kinetics were recorded with a-2-channit recorder (BS316 W + W, Electronic Inc).

Fluorescence decrease was analysed using following indices: half decay time $\left(t_{12}, e g\right.$ the time needed to reach the level $\left(F_{p}-F_{t}\right) / 2$, ratio of fluorescence decrease $\left(R_{f d}=\left(F_{p}-F_{t}\right) / F_{t}\right)$ and stress adaptative index $\left(A_{p}=1-[(1+\right.$ 
$\left.\left.\left.R_{f d} 735\right) /\left(1+R_{f d} 690\right)\right]\right)$. All of these were computed from manual measurements on chart recordings. During drought stress each measurement was replicated 3 times, and made before onset of illumination. For the photoinhibition study, 2 chlorophyll fluorescence kinetics were recorded for each twig before high illumination treatment, 30 min after and 1 night later.

\section{RESULTS}

\section{Plant water status}

Predawn leaf water potential $\left(\psi_{w p}\right)$ of all plants decreased rapidly after approximately 1 wk of water deprivation. Small amounts of water were added to maintain $\psi_{w p}$ between -2.0 and $-4.0 \mathrm{MPa}$. $\psi_{w p}$ time-course was similar for $Q$ petraea or $Q$ pubescens, but displayed a steeper decrease for $Q$ ilex (fig 1 ).

Leaf water content ( $L W C$ ) was lower (45\% approximately) in $Q$ ilex leaves than in $Q$ petraea or $Q$ pubescens 160 and $55 \%$ respectively). Because of a high interindividual variability, no significant reduction in LWC could be observed during drought, excepted when $\psi_{w p}$ decreased below -4.0 $M P a$. $L W C$ then decreased to $45 \% Q$ petraea leaves, $40 \%$ in $Q$ pubescens and $35 \%$ in $Q$ ilex.

\section{Effects of drought on net $\mathrm{CO}_{2}$ assimilation (A), stomatal conductance $(g)$ and $(A, C i)$ relationships}

Both $A$ and $g$ decreased in response to decreasing $\psi_{w p}$ (fig 2). The high interindividual variability observed at high $\psi_{\text {wp }}$ was not due to variations in water status. Stomatal closure and inhibition of $A$ started between -1.0 and $-2.0 \mathrm{MPa}$ in all tested species. $A$ and $g$ reached values near to zero when $\psi_{w p}$ attained $\approx-3.0 \mathrm{MPa}$ in $Q$ petraea, and $\approx-4.0 \mathrm{MPa}$ in $Q$ pubescens and $Q$ ilex.

During drought, $A$ and $g$ decreased in parallel, which led to a linear relationship and was an indication of a close coupling between both parameters (fig 3). But in well watered $Q$ ilex and $Q$ pubescens plants, this relationship did not remain linear at high conductances; in this case $A$ was probably limited by other factors. The intial slopes $(S)$ of these relationships, which give an estimate of instant water use
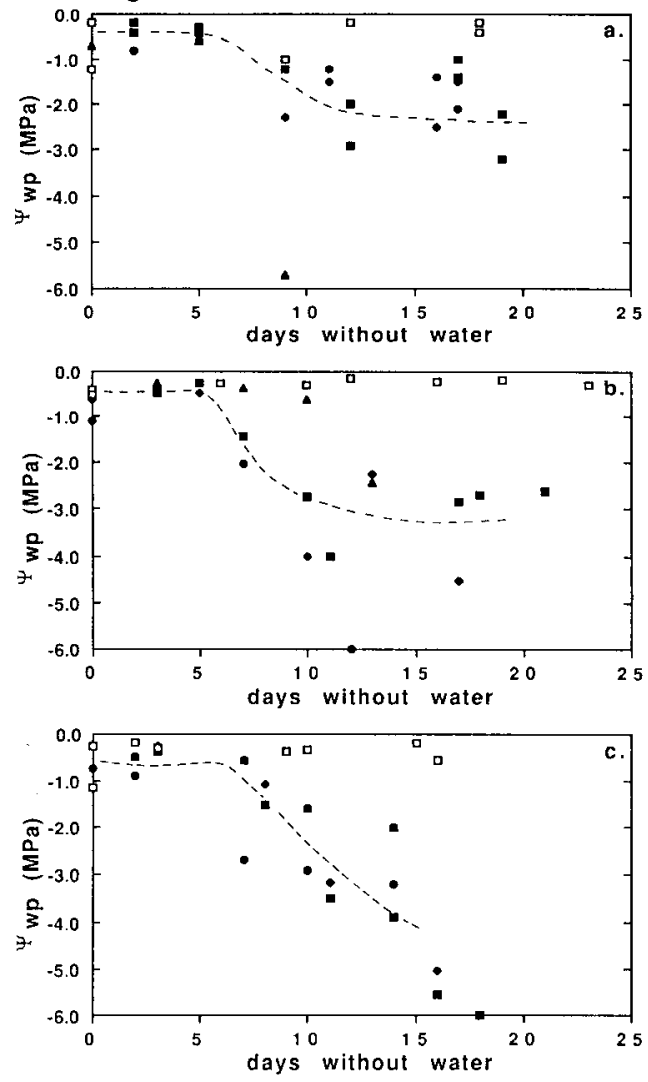

Fig 1. Time-course of predawn leaf water potential ( $\left.\psi_{\text {wp }}\right)$ of 4-5 droughted (dark symbols; one for each individual) and 2 control (open symbols) saplings of $Q$ petraea (a), $Q$ pubescens (b), and $Q$ ilex (c) during drought treatment (lines were eye-fitted). 

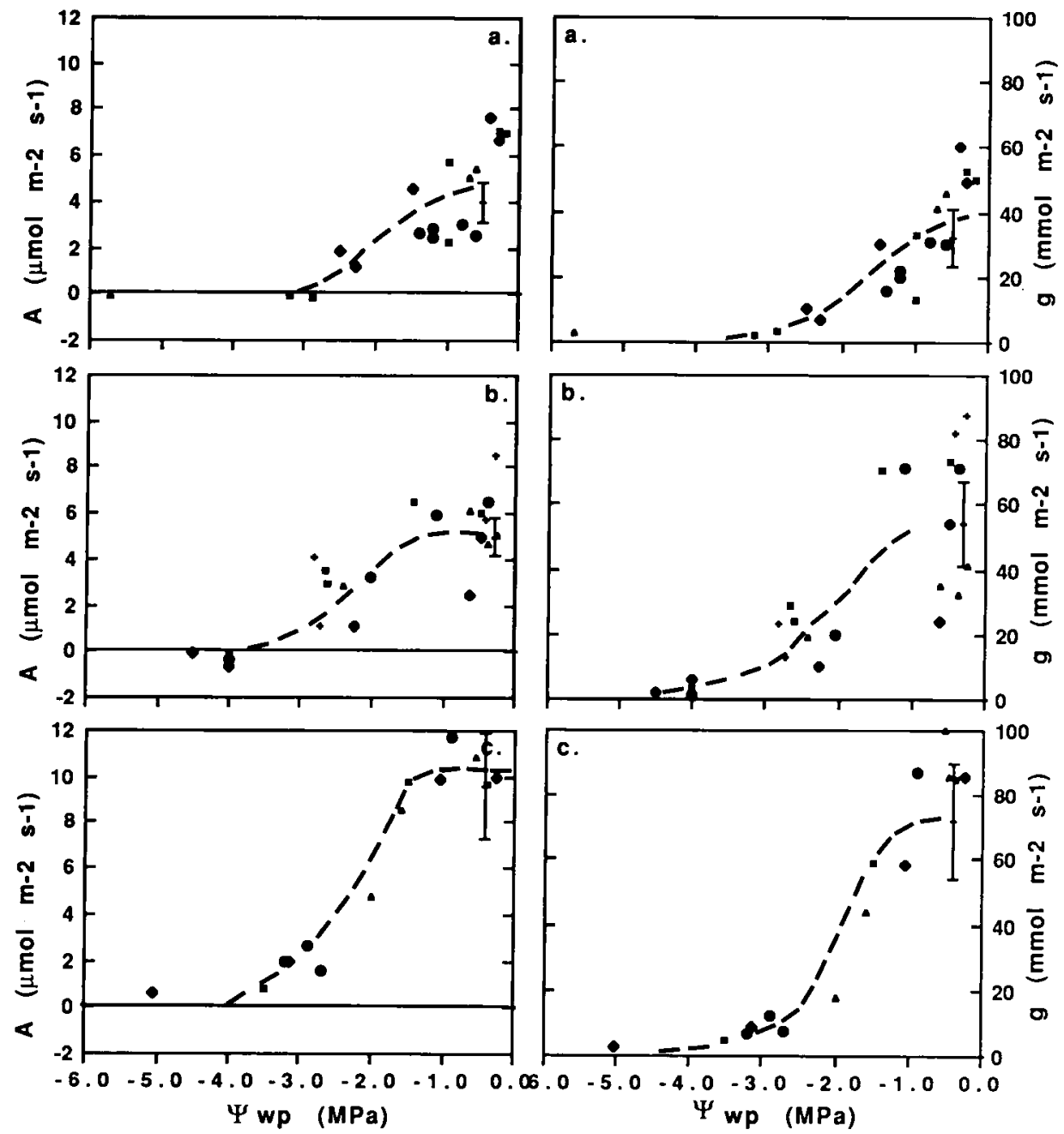

Fig 2. Net $\mathrm{CO}_{2}$ assimilation rate (A) and stomatal conductance to $\mathrm{CO}_{2}(g)$ of 4-5 droughted saplings of $Q$ petraea (a), $Q$ pubescens (b), and $Q$ ilex (c), as a function of predawn leaf water potential $\left(\psi_{w 0}\right)$. Vertical bars indicate standard deviation of the mean of 5-6 replicates obtained with 2 control saplings (lines were eye-fitted).

efficiency under water shortage (Schulze and Hall, 1982), were $0.24 \mu \mathrm{mol} \cdot \mathrm{mmol}^{-1}$ in $Q$ ilex, and 0.13 and 0.15 in $Q$ petraea and $Q$ pubescens.

An example of $\left(A, C_{j}\right)$ response curves obtained during drought development on
$Q$ petraea is shown in figure 4 . Slopes of the supply functions were reduced due to stomatal closure with declining $\psi_{w p}$, but the demand functions were also modified, which could indicate that both stomatal and non stomatal factors contributed to the 

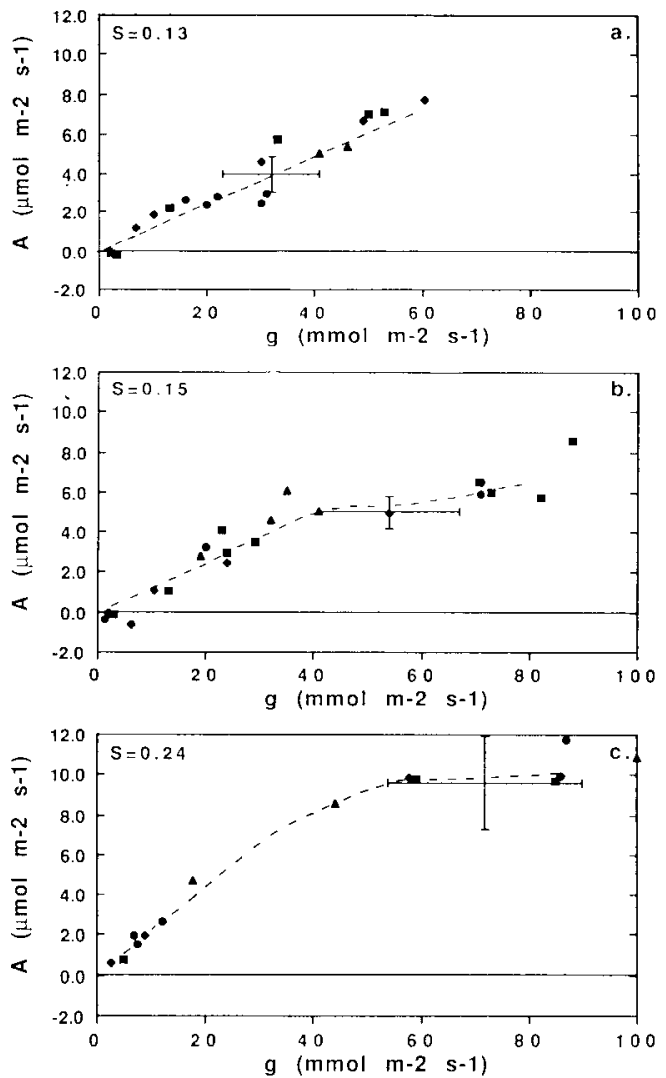

Fig 3. Relationship between net $\mathrm{CO}_{2}$ assimilation rate (A) and stomatal conductance to $\mathrm{CO}_{2}$ (g) during drought progression for 4-5 droughted saplings of $Q$ petraea (a), $Q$ pubescens (b), and $Q$ ilex (c). Vertical and horizontal bars indicate standard deviation of the mean of 5 or 6 replicates obtained with 2 control saplings. Values of initial slopes of regression $\left(\mathrm{S}, \mu \mathrm{mol} \mathrm{CO}_{2}\right.$ $\mathrm{mmol}^{-1} \mathrm{H}_{2} \mathrm{O}$ ) are displayed (lines were eyefitted).

drought induced decline in $A$. The maximal $\mathrm{CO}_{2}$ assimilation rate $\left(A_{\text {max }}\right)$ decreased first, as soon as $A$ and $g$ were inhibited. In contrast, the initial slope of the $\left(A, C_{j}\right)$ response curves $\left(\mathrm{d} A / \mathrm{d} C_{j}\right)$ remained constant until $\psi_{\text {wp }}$ values fell to below $\approx-2.0$ to $-3.0 \mathrm{MPa}$. Nevertheless, we observed a close relationship between $A$ at $350 \mu \mathrm{mol}$ $\mathrm{mol}^{-1}$ and $\mathrm{d} A / \mathrm{d} C_{i}$ during drought (fig 5 ).

\section{Effects of drought on chlorophyll a fluorescence}

All tested species displayed similar shapes for chlorophyll a fluorescence kinetics while well watered, with a fairly large interindividual variability; $Q$ ilex alone showed slightly lower values for $R_{f d}(4-5), A_{p}(\approx$ 0.25 ) and higher $t_{1 / 2}$ (30 s instead of $\approx 15 \mathrm{~s}$ for both $Q$ petraea and $Q$ robur, see figs 6 and 7$)$. These differences are probably related to the optical properties of the leaves; in fact, $Q$ ilex leaves exhibit thicker cuticules and mesophyll tissues. For all 3 species, no effect of water stress could be observed on $t_{1 / 2}, R_{f d}$ or $A_{p}$ for $\psi_{w p}$ values $>-3.0 \mathrm{MPa}$ for $Q$ petraea, and $-4.0 \mathrm{MPa}$ for $Q$ pubescens. With $Q$ ilex a slight decrease was observed till $-3.5 \mathrm{MPa}$ for $R_{f d}$ and $A_{p}$, but $t_{1 / 2}$ did not increase significantly with the exception of one case (figs 6 and 7). When stress became extremely severe, ie in 1 case at $\psi_{w p}<-5.0 \mathrm{MPa}$ for both $Q$ petraea and $Q$ pubescens, and in 3 cases < -4.0 MPa for $Q$ ilex, $t_{1 / 2}$ increased strongly while $R_{f d}$ decreased markedly, and $A_{p}$ seemed less affected. Chlorophyll fluorescence kinetics as exemplified in figure $8 \mathrm{a}$ then displayed both a decrease in peak fluorescence $\left(F_{p}\right)$ and an increase in steady state fluorescence $\left(F_{t}\right)$.

Leaf discs were submitted to rapid dehydration in vitro in free air and obscurity ( $L W C$ was reduced from 70 to $30 \%$ in $5 \mathrm{~h}$ ) to ensure that $R_{f d}, A_{p}$ and $t_{1 / 2}$ could really be affected by strong stresses, and that the previously observed stability was not an artefact. In this case, both $R_{f d}$ and $A_{p}$ decreased markedly while $t_{1 / 2}$ increased strongly (fig 9). But an important difference appeared as compared to in situ dehydration: $F_{p}$ level was not affected (fig $8 b$ ). Once again, $A_{p}$ seemed to be less affected than $R_{f d}$, and a severe water loss was necessary to induce $R_{f d}$ decrease. 


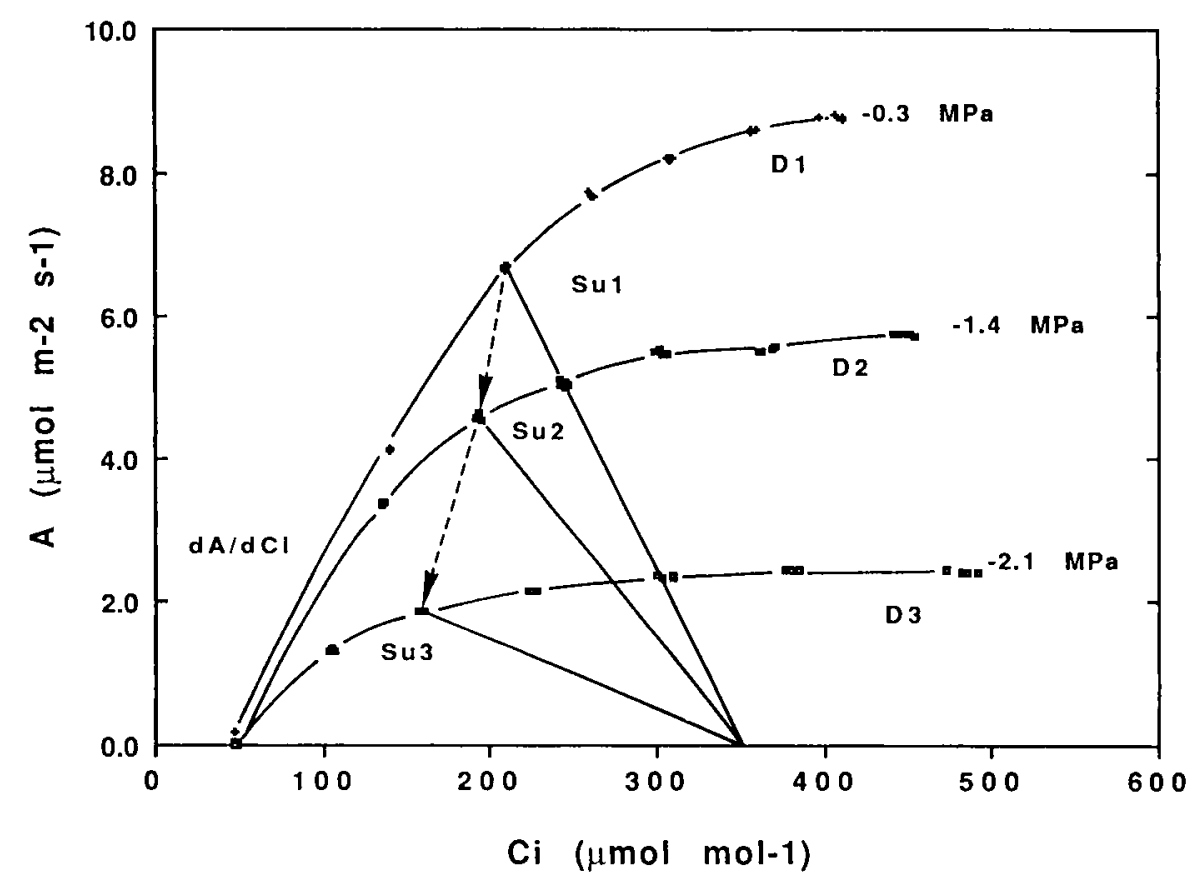

Fig 4. Net $\mathrm{CO}_{2}$ assimilation rate (A) against intercellular $\mathrm{CO}_{2}$ molar fraction $\left(C_{j}\right)$ for a sapling of $Q$ petraea at different levels of predawn leaf water potential $(-0.3 ;-1.4 ;-2.1 \mathrm{MPA}) . \mathrm{D}_{(1,2,3)}$, demand functions; $\mathrm{Su}_{(1,2,3)}$, supply functions; $\mathrm{dA} / \mathrm{dCi}$, initial slope. Dashed arrows indicate the decrease due both to decreasing stomatal conductance and mesophyll photosynthetic capacity between 2 successive levels of $\psi_{\text {wp }}$.

\section{Susceptibility to photoinhibition}

Results of these experiments are presented in table I. High illumination treatments induced a decrease of the apparent quantum yield of photosynthesis $(\alpha)$. Wellwatered plants of $Q$ petraea displayed a larger decrease than $Q$ pubescens and $Q$ ilex. But, when drought was imposed, $\alpha$ was strongly reduced (> 70\%) in $Q$ petraea and $Q$ pubescens. In contrast, $Q$ ilex water-stressed plants exhibited approximately the same reduction in $\alpha$ as well-watered ones.

$R_{f d}$ was strongly reduced in all species, excepted for well-watered $Q$ ilex. Fluores- cence kinetics exhibited a strong decrease in $F_{p}$ level, but $t_{1 / 2}$ and the form of the fluorescence decrease were not affected (fig 8c). Recovery after $12 \mathrm{~h}$ of darkness following the high illumination treatment was less in water-stressed than in well-watered plants, especially in $Q$ pubescens. Recovery was more pronounced in both control and stressed $Q$ ilex saplings than in the other species.

\section{DISCUSSION}

Quercus ilex and $Q$ pubescens exhibited similar decreases of net $\mathrm{CO}_{2}$ assimilation 

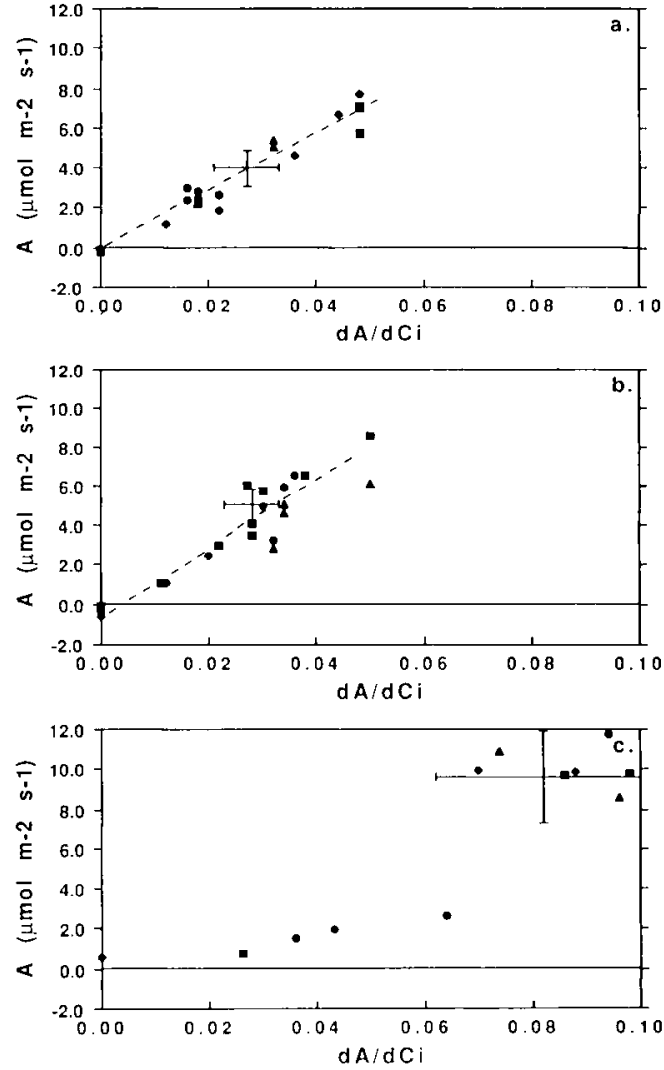

Fig 5. Relationship between the initial slope of $\left(A, C_{i}\right)$ response curves $\left(\mathrm{d} A / \mathrm{d} C_{i}\right)$ and net $\mathrm{CO}_{2}$ assimilation rate at $350 \mu \mathrm{mol} \cdot \mathrm{mol}^{-1}(A)$ during drought progression for 4-5 droughted saplings of $Q$ petraea (a), $Q$ pubescens.(b), and $Q$ ilex (c). Vertical and horizontal bars indicate standard deviation of the mean of 5-6 replicates obtained with 2 control saplings (lines were eyefitted).

rate (A) and stomatal conductance for $\mathrm{CO}_{2}$ (g) with increasing drought. Due to a large interindividual variability, no unequivocal difference in sensitivity could be detected, even if $Q$ petraea showed earlier responses to decreasing $\psi_{w p}$. In $Q$ ilex, decreases in $A$ and $g$ were steep, with higher initial values, but the overall evolution was
Table I. Apparent quantum yield of photosynthesis $(\alpha)$ measured as the initial slope of $(A$, PPFD) curves, 30 min after photoinhibitory treatment, and ratios, of fluorescence decrease measured 0.5 and $12 \mathrm{~h}\left(R_{f d_{0.5 \mathrm{~h}}}\right.$ and $\left.R_{f d_{12 \mathrm{~h}}}\right)$ after photoinhibitory treatment on control and waterstressed $\left(\psi_{w 0} \approx-2.0 \mathrm{MPa}\right.$ in $Q$ petraea, -3.0 $\mathrm{MPa}$ in $Q$ pubescens and $Q$ ilex) plants, expressed as $\%$ of their initial values. Data are means of 2 saplings ( 3 for $Q$ ilex stressed plants). $R_{f d}$ was recorded twice on each sapling.

\begin{tabular}{llccc}
\hline Species & Treatment & $\begin{array}{c}\alpha \\
(\%)\end{array}$ & $\begin{array}{c}\mathrm{R}_{\text {fdo.5h }} \\
(\%)\end{array}$ & $\begin{array}{c}\mathrm{R}_{\text {fdiah }} \\
(\%)\end{array}$ \\
\hline \multirow{2}{*}{ Qpetraea } & Control & 42 & 34 & 78 \\
Q pubescens & Stressed & 27 & 38 & 62 \\
\multirow{2}{*}{ Q ilex } & Control & 68 & 36 & 69 \\
& Stressed & 28 & 37 & 38 \\
& Control & 66 & 60 & 94 \\
& Stressed & 60 & 44 & 87 \\
\hline
\end{tabular}

not very different from that of the previous species. During the entire experiment a close coupling was observed between decreases in $A$ and $g$. Parallel decreases in $A$ and $g$ in response to decreasing $\psi_{w p}$ have often been reported (Wong et al, 1985; Teskey et al, 1986; Di Marco et al, 1988). $A / g$ increased during drought progression, and reached constant values with a higher water use efficiency $(\mathrm{d} A / \mathrm{d} g$ ) for $Q$ ilex than for $Q$ petraea or $Q$ pubescens under limited water supply.

Alteration of $\left(A, C_{j}\right)$ relationships showed that apparently both stomatal and non stomatal factors contributed to the limitation of $A$. The maximal rate of net $\mathrm{CO}_{2}$ assimilation at high $C_{i}\left(A_{\max }\right)$ was first affected. According to von Caemmerer and Farquhar (1981) and Farquhar and Sharkey (1982), this could mean a decrease in the rate of regeneration of ribulose $1,5 \mathrm{bi}$ sphosphate $\left(\mathrm{RUP}_{2}\right)$ which could be limited by reduced photophosphorylation associa- 

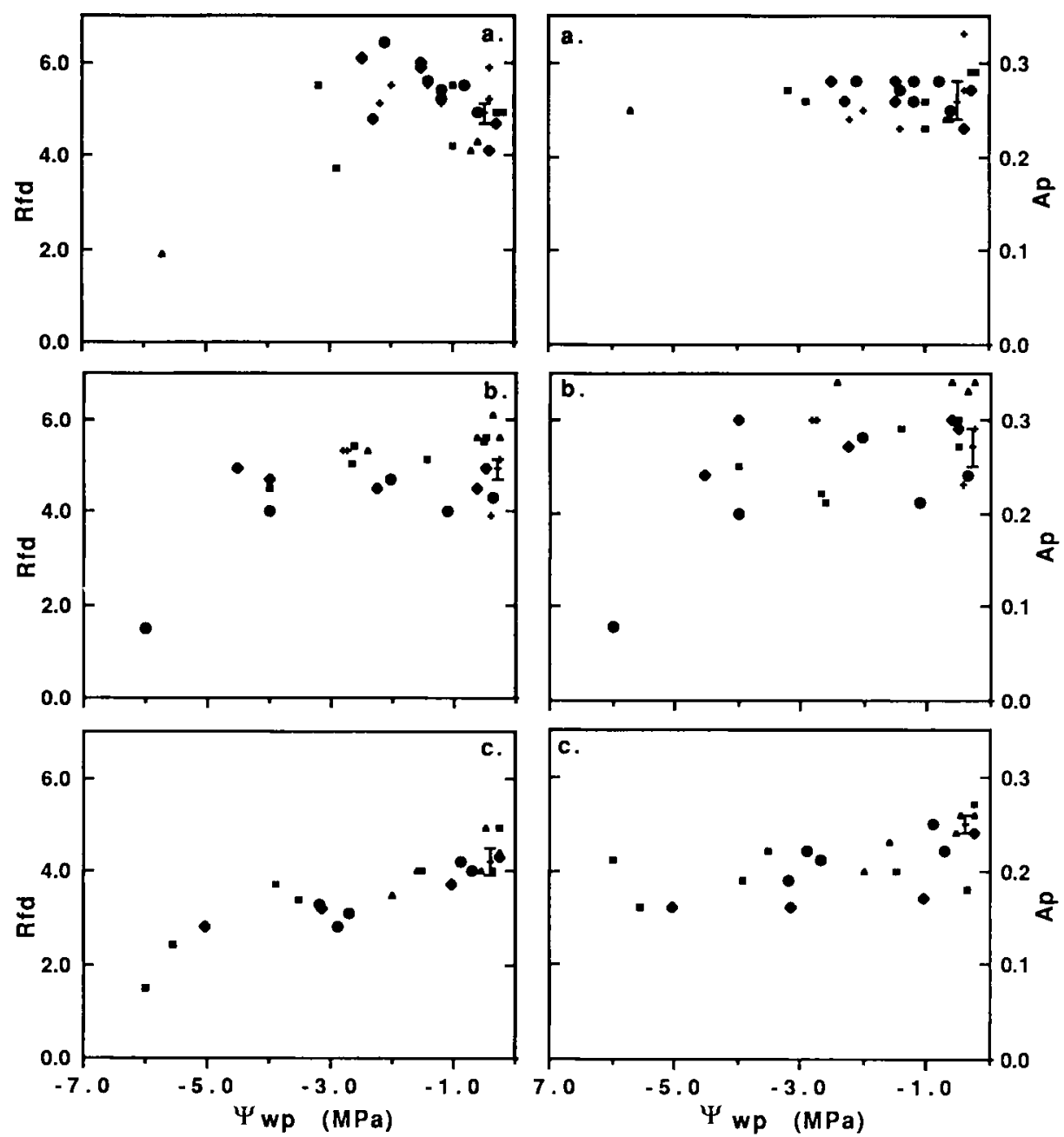

Fig 6. Ratio of fluorescence decrease $\left(R_{f o}\right)$ and adaptation index $\left(A_{p}\right)$ of 4-5 droughted saplings of $Q$ petraea (a), $Q$ pubescens (b), and $Q$ ilex (c), expressed as a function of predawn leaf water potential $\left(\psi_{w p}\right)$. Each point is the mean of 3 replicates on 1 sapling and vertical bars indicate standard deviation of the mean obtained with $18-24$ replicates on 2 control saplings.

ted with electron transport, or by a starvation in stromal $P_{j}$ (Sharkey, 1985). The decrease in $\mathrm{d} A / \mathrm{d} C_{i}$ could result from a decrease in carboxylation efficiency (von Caemmerer and Farquhar, 1981). Earlier results showed similar alterations in $\left(A, C_{j}\right)$ relationships (Jones and Fanjul, 1983;
Teskey et al, 1986; Ögren and Öquist, 1985; Kirschbaum, 1987; Cornic et al, 1987; Grieu et al, 1988). Farquhar and Sharkey (1982) have also reported that the first effects of water stress were a reduction of $A_{\max }$, while $\mathrm{d} A / \mathrm{d} C_{i}$ was initially unaffected. 


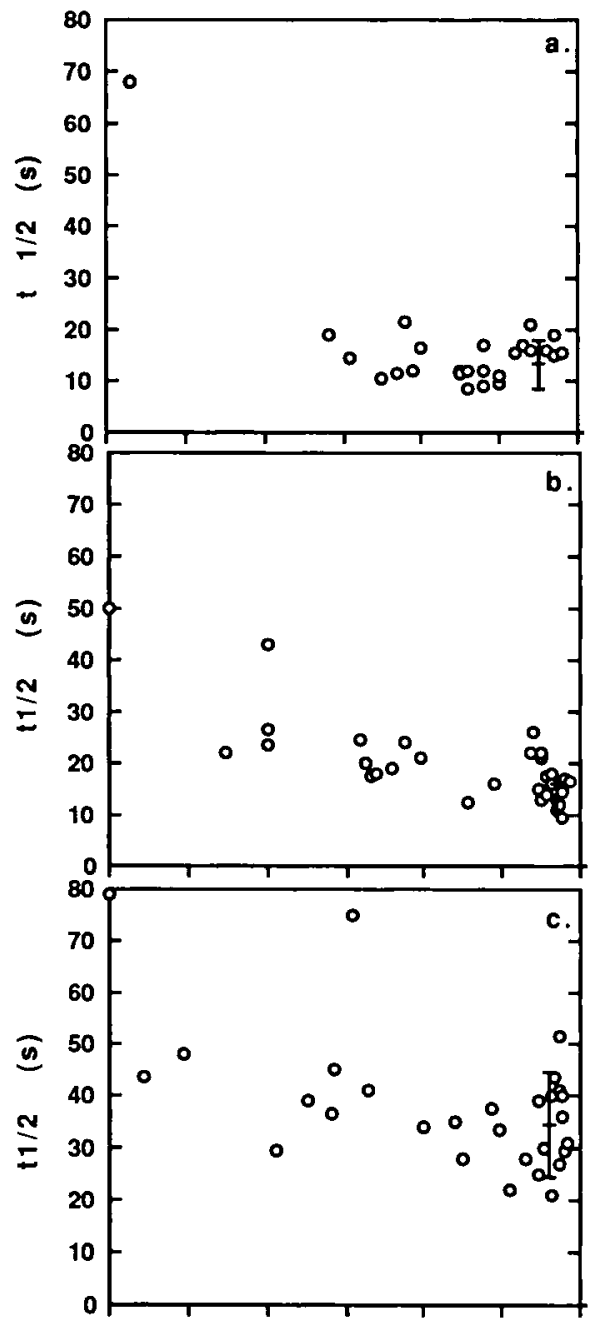

$-6.0-5.0-4.0-3.0-2.0-1.00 .0$

$\Psi$ wp (MPa)

Fig 7. Fluoresence half decay time from $F_{p}$ to $F_{t}$ level $\left(t_{1 / 2}\right)$ as measured on 4-5 droughted saplings of $Q$ petraea (a), $Q$ pubescens (b), and $Q$ ilex (c), as a function of predawn leaf water potential $\left(\psi_{\text {wp }}\right)$. Each point is the mean of 3 replicates on 1 sapling and vertical bars indicate standard deviation of the mean obtained with 18-24 replicates on 2 control saplings.
In order to obtain additional information on this apparent mesophyll limitation of net $\mathrm{CO}_{2}$ assimilation, we studied the decrease of in vivo fluorescence during the onset of drought. Surprisingly, half decay time $\left(t_{1 / 2}\right)$, ratio of fluorescence decrease $\left(R_{f d}\right)$ and stress adaptation index $\left(A_{p}\right)$ were not affected by drought until $\psi_{w p}$ reached values $<-4.0 \mathrm{MPa}$, that is well below turgor loss in these species $(-2.0$ in $Q$ petraea, -2.8 in $Q$ pubescens and -2.4 in $Q$ ilex under similar conditions; Dreyer et al, 1990). The absence of an effect of water stress on the initial rise in fluorescence has been frequently reported (Ögren and Öquist, 1985; Genty et al, 1987; Toivonen and Vidauer, 1988; di Marco et al, 1988), indicating that PSII photochemistry is quite resistant to leaf water deficits. The absence of a decrease in $F_{p}$ levels in relation to water stress which we observed is in agreement with this view. The evolution of $R_{f d}$ and $A_{p}$ under leaf water stress has seldom been documented; however, Schwab et al (1989) showed the stability of $R_{f d}$ in Spinacia oleracea and in resurrection plants until relative water content declined to $40 \%$. In addition to the same $R_{f d}$ stability we also observed a remarkably constant half decay time $\left(t_{1 / 2}\right)$. In fact, the decrease in fluorescence following the $F_{p}$ peak results both from photochemica quenching $\left(Q_{p}\right)$ and non photochemical quenching $\left(Q_{n \rho}\right)$. The former is due to reoxidation of the primary electron acceptor of PSII during the onset of carbon reduction, and the latter results largely from thermal deexcitation of PSII associated with the building up of transthylakoidal proton gradients and to a lesser extent from the transfer of excitation energy from PSII to PSI (Krause and Weis, 1984; Briantais et al, 1986; Krause et al, 1988). The remarkable stability of both $R_{f d}$ and $t_{1 / 2}$ observed in our experiments could be an argument in favour of a stability of both $Q_{p}$ and $Q_{n p}$. This hy- 


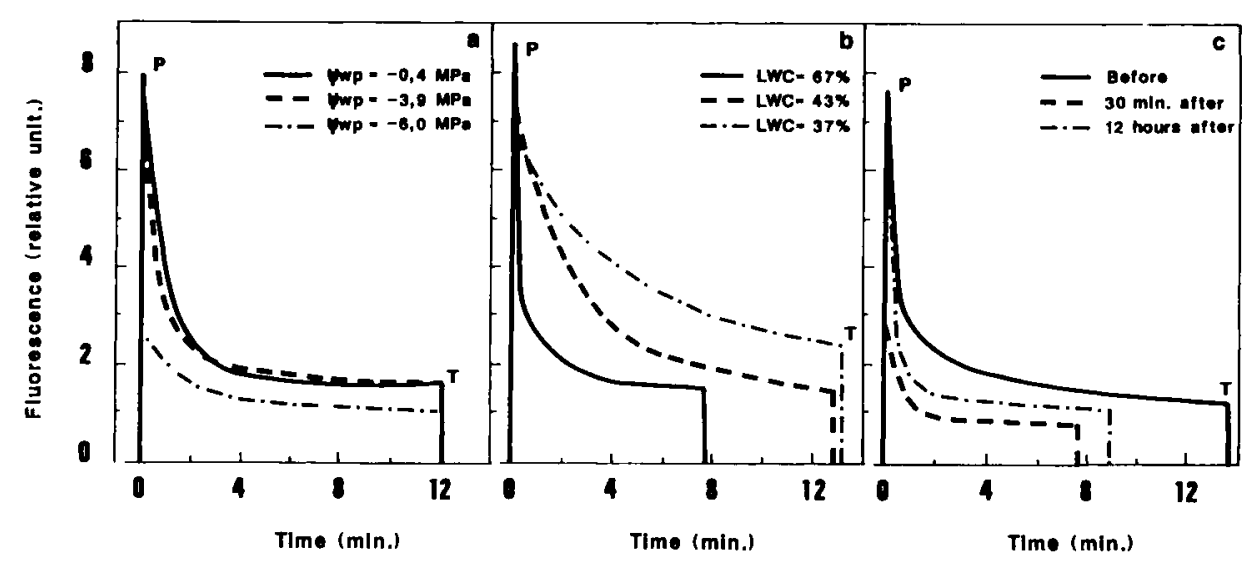

Fig 8. Chlorophyll fluorescence transients measured after 30 min of dark acclimation, at $690 \mathrm{~nm}$ of leaf disks; a) during in situ water shortage in $Q$ pubescens; $b)$ during rapid dehydration of $Q$ petraea leaf disk; and c) before, 0.5 or $12 \mathrm{~h}$ after high light treatments in $Q$ pubescens. $\mathrm{P}$ and $\mathrm{T}$ respectively indicate $F_{p}$ and $F_{t}$ levels.

pothesis is in agreement with the observations of Stuhlfauth et al, 1988 (with Digitalis lanata). Constancy of these parameters implies a stability of both the electron flow from PSIl to the primary acceptors, and

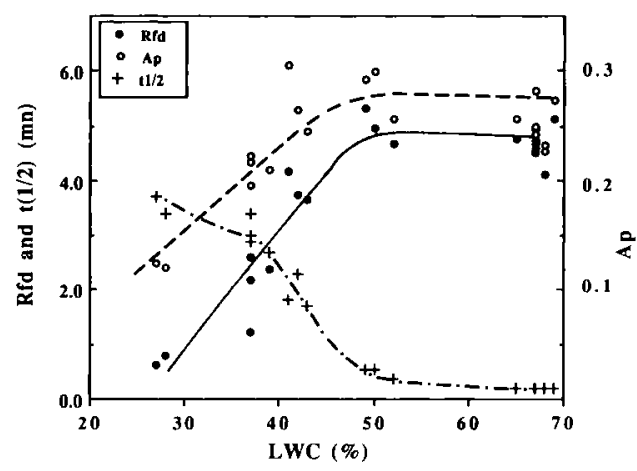

Fig 9. Relationship between leaf water content (LWC) of in vitro drying leaf disks of $Q$ petraea and ratio of fluorescence decrease $\left(R_{f d}\right.$ dark symbols), adaptation index ( $A_{p}$, open symbols) and half decay time from $F_{p}$ to $F_{p}$ level $\left(t_{1 / 2}\right)$ during rapid dehydratation in air and obscurity. Each point represents an individual value (lines were eye-fitted). the intensity of thermal de-excitation of PSII. Electron flow could be maintained at low values of $C_{i}$ through photorespiratory $\mathrm{CO}_{2}$, recycling (Osmond et al, 1980; André, 1986). A reduction in the initial slope of $F_{p}$ to $F_{t}$ decline (ie an increase in $t_{1 / 2}$ ) was observed during drought with higher illuminations by Di Marco et al, 1988 (with Triticum durum); Genty et al, 1987 (with Gossypium hirsutum); Ögren and Öquist, 1985 (with Salix sp); Epron and Dreyer (unpublished observations with Populus $\mathrm{sp})$. The stability we obtained with our oak species may therefore not be a general feature under different conditions and in other species.

The results obtained from gas exchange and chlorophyll fluorescence studies therefore appear contradictory:

- the evolution of $\left(A, C_{j}\right)$ relationship indicated the appearance of mesophyll limitations of photosynthesis during drought; and

- conversely, fluorescence data showed the absence of any major impairment in 
photosynthetic apparatus during leaf water deficit. According to Terashima et al (1988), values of $C_{i}$ could be overestimated if patchy stomatal closure occurred in water-stressed leaves. Non uniform stomatal closure has been reported in response to ABA application in Helianthus annuus, Vitis vinifera and Vicia faba (Downton et al, 1988a; Terashima et al, 1988) and in response to water stress in Vitis vinifera, $\mathrm{Ne}$ rium oleander, Eucalyptus pauciflora and Phaseolus vulgaris (Downton et al, 1988b; Sharkey and Seeman, 1989). If $C_{i}$ values were overestimated, $\mathrm{d} A / \mathrm{d} C_{i}$ and $A_{\max }$ would be underestimated and the apparent non-stomatal inhibition of photosynthesis would be an artefact. Using another method, Kaiser (1987) and Cornic et al (1989) showed that apparent quantum yield and maximal rate of photosynthetic $\mathrm{O}_{2}$ evolution measured with a $\mathrm{CO}_{2}$ concentration of up to $5 \%$ which overcame diffusive resistance did not decline with water stress until there was a severe water loss $(20-40 \%)$, indicating a high resistance of the photosynthetic apparatus. Patchy stomatal closure has not yet been studied in water-stressed oak leaves. Anyway, our results seem to indicate that the mesophyll photosynthetic capacity is rather insensitive to drought stress in the 3 oak species and that observed inhibition of net $\mathrm{CO}_{2}$ assimilation seemed to be related mostly to stomatal closure and limitations of $\mathrm{CO}_{2}$ diffusion into the leaves, at least during the first stages of dehydration.

When drought stress became more severe $\left(\psi_{w p}<-4.0 \mathrm{MPa}\right)$, both $R_{f d}$ and $A_{p}$ decreased and $t_{1 / 2}$ increased, indicating possible damage to the photosynthetic apparatus. The same results were obtained with leaf discs of $Q$ petraea submitted to rapid dehydratation in air. After large water losses, $F_{t}$ level and $F_{p}$ to $F_{t}$ half decay time $\left(t_{1 / 2}\right)$ increased. However, $F_{p}$ levels were not affected by a rapid in vitro dehydrata- tion of leaf discs, while they showed strong reductions during a severe drought stress in situ. As high light treatments induced a decline in $F_{p}$ levels (fig $8 \mathrm{c}$ ), we suggest that photoinhibitory damage could have arisen when severe water stress was imposed on our saplings in situ and after carbon reduction was impaired. During leaf disc dehydration, carbon reduction was also impaired but water stress was very rapidly imposed in darkness. Kaiser (1987) has suggested that the inhibition of stromal enzymes by increasing electrolyte concentrations or by extremely high protein concentrations induced impairment of carbon reduction during severe drought stress, but that high irradiance density could be responsible for photoinhibitory damages under natural drought conditions.

Because we could not observe any alteration in the fluorescence kinetics over the entire ecophysiologically significant range of $\psi_{w p}$ ( $i e$, between 0 and -4.0 $\mathrm{MPa}$ ), it appears that our plants did not suffer from photoinhibition during imposition of water stress under our light conditions. Powles et al (1984) have shown that maintenance of a minimal level of carbon reduction (by photorespiratory $\mathrm{CO}_{2}$ recycling) prevents photoinhibition in leaves.

In leaves exposed to drought, photoinhibition of photosynthesis by high light treatments was more pronounced, especially in $Q$ petraea and $Q$ pubescens, as has been previously reported for Salix sp leaves (Ögren and Öquist, 1985). The decrease in the apparent quantum yield of net $\mathrm{CO}_{2}$ assimilation and of $F_{p}$ levels of chlorophyll fluorescence kinetics show that electron transport, and particularly PSII activity were inhibited (Powles, 1984). Recovery after photoinhibition was lower after $12 \mathrm{~h}$ in $Q$ petraea and $Q$ pubescens waterstressed leaves. As recovery from photoinhibition is known to be partly due to protein synthesis in the chloroplasts (Greer et al, 
1986; Legouallec and Cornic, 1988), we suggest that the lesser extent of recovery in water-stressed leaves of $Q$ petraea and $Q$ pubescens may result from inhibition of protein synthesis during water stress. $Q$ ilex leaves appeared to be less sensitive to high light treatments because they recovered even when drought stressed, perhaps because of protective mechanisms which would enhance thermal dissipation of excess light energy (Demmig et al, 1987 ; Krause, 1988). In addition, it is possible that the ratio of absorbed $P P F D$ to incident $P P F D$ is lower in $Q$ ilex leaves because of adaptations in leaf morphology and anatomy (higher leaf and cuticule thickness). Clearly, as differences in susceptibility to photoinhibition associated with water stress may play a major role as an adaptative mechanism to drought under natural conditions in forest ecosystems, further studies are required to document their occurrence.

In conclusion, the differences in sensitivity to drought between the 3 oak species studied do not seem to rely on a direct sensitivity of the photosynthetic apparatus to leaf water deficit. There is evidence for an increase of the instantaneous water use efficiency during drought progression in $Q$ pubescens and $Q$ ilex, and instantaneous water use efficiency was higher in $Q$ ilex both in well watered and in droughtexposed leaves. However, the better adaptation of $Q$ ilex under natural drought conditions could be mainly related to its lower susceptibility to photoinhibition, even during water shortage.

\section{ACKNOWLEDGMENTS}

The authors thank $P$ Gross for designing the gas exchange measurement system, JM Gioria for breeding the plants, JM Guehl for advice in preparing the manuscript and two anonymous reviewers for helpful criticism.

\section{REFERENCES}

André M (1986) Capacité oxydative et résistance à la sécheresse de différentes plantes supérieures $\mathrm{CAM}-\mathrm{C} 3-\mathrm{C} 4$ et de végétaux inférieurs. Bull Soc Bot Fr 133, Lettres Bot 207212

Boyer JS (1976) Water deficits and photosynthesis. In: Water Deficits and Plant Growth (Kozlowsky TT, ed) Academic Press, NY, pp 153190

Briantais JM, Vernotte C, Krause GH, Weis E (1986) Chlorophyll a fluorescence of higher plants: chloroplasts and leaves. In: Light Emission by Plants and Bacteria (Govindgee J, Amesz OJ, Fork, eds) Academic Press, NY, 539-583

von Caemmerer S, Farquhar GD (1981) Some relationships between the biochemistry of photosynthesis and the gas exchange of leaves. Planta 153, 376-387

Cornic G, Prioul JL, Louason G (1983) Stomatal and non stomatal contribution to reductions in leaf net $\mathrm{CO}_{2}$ uptake during rapid water stress. Physiol Plant 58, 295-301

Cornic G, Papagiorgiou I, Louason G (1987) Effect of a rapid and a slow drought cycle followed by rehydration on stomatal and non stomatal components of leaf photosynthesis in Phaseolus vulgaris L. J Plant Physiol 126, 309-318

Cornic G, Le Gouallec JL, Briantais JM, Hodges $M$ (1989) Effect of dehydratation and high light on photosynthesis of two $\mathrm{C} 3$ plants (Phaseolus vulgaris L, Elatostema repens (Lour) Hall f). Planta 177, 84-90

Demmig B, Winter $K$, Krüger A, Czygan FC (1987) Photoinhibition and zeaxanthin formation in intact leaves. A possible role of the xanthophyll cycle in the dissipation of excess light energy. Plant Physio/ 84, 218-224

Downton WJS, Loveys BR, Grant WJR (1988a) Stomatal closure fully accounts for the inhibition of photosynthesis by abscisic acid. New Phytcl 108, 263-266

Downton WJS, Loveys BR, Grant WJR (1988b) Non uniform stomatal closure induced by water stress causes putative non stomatal inhibition of photosynthesis. New Phytol 110, 503-509 
Dreyer E, Bousquet F, Ducrey M (1990) Use of pressure-volume curves in water relation analysis on woody shoots: influence of rehydration and comparison of four European oak species. Ann Sci For 47 (in press)

Farquhar GD, Sharkey TD (1982) Stomatal conductance and photosynthesis. Ann Rev Plant Physio/ 33, 317-345

Genty B, Briantais JM, Viera da Silva JB (1987) Effects of drought on primary photosynthetic processes of cotton leaves. Plant Physiol 83, 360-364

Greer DH, Berry JA, Björkman O (1986) Photoinhibition of photosynthesis in intact bean leaves: role of light and temperature, and requirement for chloroplast-protein synthesis during recovery. Planta 168, 253-260

Grieu P, Guehl JM, Aussenac G (1988) The effects of soil and atmospheric drought on photosynthesis and stomatal control of gas exchange in three coniferous species. Physiol Plant 73, 97-104

Guehl JM, Aussenac G (1987) Photosynthesis decrease and stomatal control of gas exchange in Abies alba Mill in response to vapor pressure deficit. Plant Physiol 83, 316322

Jones HG (1973) Limiting factors in photosynthesis. New Phytol 72, 1089-1094

Jones HG (1973) Partitioning stomatal and non stomatal limitations to photosynthesis. Plant, Cell Environ 8, 98-104

Jones HG, Fanjul L (1983) Effects of water stress and $\mathrm{CO}_{2}$ exchange in apple. In: Stress Effects on Photosynthesis ( $R$ Marcelle, ed), 75-84

Kaiser WM (1987) Effects of water deficit on photosynthetic capacity. Physiol Plant 71, 142-149

Kirschbaum MUK (1987) Water stress in Eucalyptus pauciflora: comparison of effects on stomatal conductance with effects on the mesophyll capacity for photosynthesis, and investigation of a possible involvement of photoinhibition. Planta 171, 466-473

Krause GH, Weis E (1984) Chlorophyll fluorescence as a tool in plant physiology: II. Interpretation of fluorescence signals. Photosynth Res 5, 139-157

Krause GH (1988) Photoinhibition of photosynthesis. An evaluation of damaging and pro- tective mechanisms. Physiol Plant 74, 566574

Krause GH, Laasch H, Weis E (1988) Regulation of thermal dissipation of absorbed light energy in chloroplasts indicated by energydependent fluorescence quenching. Plant Physiol Biochem 26, 445-452

Le Gouallec JL, Cornic G (1988) Photoinhibition of photosynthesis in Elatostema repens. Plant Physiol Biochem 26, 705-715

Lichtenthaler HK, Buschmann C, Rinderle U, Schmuck G (1986) Application of chlorophyll fluorescence in ecophysiology. Radiat Environ Biophys 25, 297-308

Lichtenhaler HK, Rinderle U (1988) The role of chlorophyll fluorescence in the detection of stress conditions in plants. Crit Rev Analyt Chem 19 (S1), 29-85

Di Marco G, Massacri A, Gabrielli R (1988) Drought effects on photosynthesis and fluorescence in hard wheat cultivars grown in the field. Physiol Plant 74, 385-390

Osmond CB, Winter K, Powles SB (1980) Adaptive significance of carbon dioxide cycle during photosynthesis in water-stressed plants. In: Adaptation of Plants to Water and High Temperature Stress (Turner NC, Kramer PJ, eds) John Wiley and Sons, 139-154

Ögren E, Öquist G (1985) Effects of drought on photosynthesis, chlorophyll fluorescence and photoinhibition susceptibility in intact willow leaves. Planta 166, 380-388

Powles SB (1984) Photoinhibition of photosynthesis induced by visible light. Ann Rev Plant Physiol 35, 15-44

Powles SB, Cornic G, Louason G (1984) Photoinhibition of photosynthesis induced by strong light in the absence of $\mathrm{CO}_{2}$ : an appraisal of the hypothesis that photorespiration protects against photoinhibition. Physiol Vég 22, 437-446

Schulze ED, Hall AE (1982) Stomatal responses, water loss and $\mathrm{CO}_{2}$ assimilation rates of plants in contrasting environments. In: Physiological Plant Ecology II: Water Relations and Carbon Assimilation (Lange OL, Nobel PS, Osmond $\mathrm{CB}$, Ziegler $\mathrm{H}$, eds) Springer Verlag, Berlin, 263-324

Schwab KB, Schreiber U, Hever U (1989) Response of photosynthesis and respiration of resurrection plants to dessication and rehydration. Planta 177, 217-227 
Sharkey TD (1985) Photosynthesis in intact leaves of C3 plants : physics, physiology and rate limitations. Bot Rev 51 (1), 53-105

Sharkey TD, Seemann JR (1989) Mild water stress effects on carbon reduction cycle intermediates, ribulose biphosphate carboxylase activity and spatial homogeneity of photosynthesis in intact leaves. Plant Physiol 89 , 1060-1065

Strasser RJ, Schwarz B, Bucher JB (1987) Simultane Messung der Chlorophylifluorescenz-kinetik bei vercheidenen Wellenlängen als rasches Verfahren zur Frühdiagnose von Immisionsbelastungen an Walbäumen: Ozoneinwirkungen auf Buchen und Pappeln. Eur For Pathol 17, 149-

Stuhfauth T, Sültemeyer DF, Weinz S, Fock HP (1988) Fluorescence quenching and gas exchange in a water stressed C3 plant, Digitalis lanata. Plant Physiol 86, 246-250

Terashima I, Wong SC, Osmond $\mathrm{CB}$, Farquhar GD (1988) Characterisation of non-uniform photosynthesis induced by abscisic acid in leaves having different mesophyll anatomy. Plant Cell Physiol 29, 385-394

Teskey RO, Fiotes JA, Samuelson LJ, Bongarten BC (1986) Stomatal and non stomatal limitations to net photosynthesis in Pinus taeda $\mathrm{L}$ under different environmental conditions. Tree Physiol 2, 131-142

Toivonen P, Vidaver W (1988) Variable chlorophyll a fluorescence and $\mathrm{CO}_{2}$ uptake in water stress white spruce seedlings. Plant Physiol 86, 744-748

Vu JCV, Allen LH Jr, Bowes G (1987) Drought stress and elevated $\mathrm{CO}_{2}$ effects on soybean ribulose bisphosphate carboxylase activity and canopy photosynthetic rates. Plant Physiol 83, 573-578

Wong SC, Cowan IR, Farquhar GD (1985) Leaf conductance in relation to rate of $\mathrm{CO}_{2}$ assimilation. III. Influences of water stress and photoinhibition. Plant Physiol 78, 830-834 